\title{
Is polycystic ovarian syndrome and insulin resistance associated with abnormal uterine bleeding in adolescents?
}

\author{
Ewa Urbanska' ${ }^{1}$, Lidia Hirnle ${ }^{2}$, Magdalena Olszanecka-Glinianowicz ${ }^{3}$, Violetta Skrzypulec- \\ Plinta ${ }^{1}$, Agnieszka Skrzypulec-Frankel ${ }^{4}$, Agnieszka Drosdzol-Cop ${ }^{1}$ \\ 'Woman's Health Chair, School of Health Sciences in Katowice, Medical University of Silesia, Katowice, Poland \\ ${ }^{2}$ Department and Clinic of Gynaecology and Obstetrics, Wroclaw Medical University, Wroclaw, Poland \\ ${ }^{3}$ Health Promotion and Obesity Management Unit, Department of Pathophysiology, Faculty of Medicine, Medical University of \\ Silesia, Katowice, Poland \\ ${ }^{4}$ Department of the Internal Disease, Dermatology and Allergy, European Center of Diagnosis and Treatment of Urticaria, \\ School of Medicine in Zabrze, Medical University of Silesia, Katowice, Poland
}

\begin{abstract}
Objectives: The aim of the study was to determine if adolescents with juvenile bleeding had polycystic ovarian syndrome (PCOS) and insulin resistance.

Material and methods: The study was conducted in a group of 43 females aged 12-18 years, diagnosed with juvenile menorrhagia, and 37 healthy female adolescents aged 12-18 years. The study was conducted during the early follicular phase of the menstrual cycle. Menstrual cycle disturbances, acne and hirsutism were recorded. Ultrasound scan determining the condition of the ovaries was conducted. Laboratory tests of the glucose level, cholesterol, LDL and HDL cholesterol and triglycerides fraction, DHEAS, FSH, LH, insulin, SHGB, total testosterone, androstenedione, and free testosterone have been established.

Results: The occurrence of regular menstrual cycles $(30.23 \%, p=0.006)$ was significantly lower in the juvenile bleeding group. Also, secondary amenorrhea was significantly more likely to be recognized in this group of females $(p=0.03)$. The concentration of FSH was considerably lower $(p=0.0002)$ in the group of adolescents with AUB.

Conclusions: Adolescents with abnormal uterine bleeding (AUB) are often diagnosed with secondary amenorrhea, and PCOS. The group with a diagnosis of juvenile bleeding was also diagnosed with higher rates of insulin resistance.

Key words: abnormal uterine bleeding; polycystic ovarian syndrome; hyperandrogenism; insulin resistance
\end{abstract}

Ginekologia Polska 2019; 90, 5: 262-269

\section{INTRODUCTION}

Abnormal uterine bleeding (AUB), or juvenile bleeding, is defined as heavy bleeding with blood clots, lasting more than 7 days and often leads to anemia. Menstrual blood loss exceeds $80 \mathrm{~mL}$ [1-5].

It has been observed that abnormal menstrual bleeding occurs in approximately $20-30 \%$ of adolescent females, and one fifth experience features relating to AUB during their first period. It is estimated that $80 \%$ of adolescent bleeding occurs one to two years after menarche $[3,4]$.

Etiopathogenesis of juvenile bleeding has not yet been fully established. It is believed that heavy menstrual bleeding in adolescence has no organic etiology, but is due to a lack of ovulation and luteal insufficiency. In these cases, menstrual cycles are not yet regular, there are no premenstrual symptoms and bleeding may start without any signals indicating the approach of menstruation [4-7].

It has also been suggested that juvenile bleeding may be associated with hormonal disorders such as polycystic ovarian syndrome (PCOS). It was observed that among some young women with PCOS, incidents of heavy menstrual bleeding had previously occurred [8].

Currently, there are only few results from large epidemiological studies which would affect the risk factors 
of the polycystic ovarian syndrome. In studies conducted on small groups of women, a significantly higher incidence of PCOS was observed among women with low birth weight, premature start of puberty and the onset of menarche over 15 years of age. A risk factor for PCOS is obesity and there are also observations being carried out on the genetics of this syndrome [9-12].

Heavy menstrual bleeding occurs frequently and can significantly impair the quality of life of adolescent females. Thorough analysis and research can help in revealing the causes of abnormal bleeding and prevent intensification of co-endocrine disorders such as acne, hirsutism, PCOS, metabolic syndrome and insulin resistance in future life [12-16].

\section{Objectives}

The aim of this research project was to assess the presence of polycystic ovarian syndrome and insulin resistance in females diagnosed with juvenile bleeding.

\section{MATERIALS AND METHODS}

\section{Study population}

The study included 43 females aged between 12 and 18 years old, who were diagnosed with abnormal uterine bleeding (AUB), and 37 healthy females of the same age range, who constituted the control group. All respondents gave written consent to carry out all the procedures included in the study protocol (in case of underage patient, consent was taken both from the participant and their parent or legal guardian). The study was approved by the Bioethics Committee of the Medical University of Silesia in Katowice (No. of consent KNW /0022/KBI/74/12).

\section{Methods}

All participants of the study had a gynecological assessment, which established menstrual cycles (length, regularity of menstrual cycle, presence of secondary amenorrhea and the length of menstrual bleeding). According to the American Society of Obstetricians and Gynecologists (ACOG), normal menstrual cycles in adolescent females last 21-45 days, and the duration of menstrual bleeding $\leq 7$ days [14]. Heavy menstrual bleeding is defined as being $>80 \mathrm{~mL}[2,4,17]$. Irregular menstrual cycles, are when the length of the cycle is shorter than 21 days (polymenorrhoea) or longer than 45 days (oligomenorrhoea) [17]. Secondary amenorrhea was defined as lack of menstrual bleeding for more than 6 months in those with a history of normal menstruation [18].

Clinical features of hyperandrogenism were based on the occurrence of features such as hirsutism, acne (diagnosed based on a subjective 10-step scale), and androgenetic alopecia. Hirsutism was assessed using the
Ferriman and Gallwey scale and was diagnosed if the score was 8 or more points $[7,18]$. In addition, between the $3 \mathrm{rd}$ and 5th day of the menstrual cycle a transabdominal ultrasound scan was conducted to assess the structure and volume of the ovaries. The diagnosis of PCOS was based on the ESHRE/ASRM criteria. Assuming that the adolescents satisfied all three criteria, and had been assessed for at least two years after menarche [19-22]. All participants also had anthropometric measurements (weight, height, waist and hips).

The survey excluded adolescents who also had significant additional systemic illnesses (e.g. coagulation disorders, hyperthyroidism, hypothyroidism, cardiovascular disease, diabetes, peptic ulcer, autoimmune diseases, other endocrine disorders, epilepsy). The study did not include females who were taking hormonal or contraceptive pills, non-steroidal anti-inflammatory drugs or have been on a restrictive diet in the last six months.

The examined adolescents in the early follicular phase of the menstrual cycle (between the 3rd and 5th day of the menstrual cycle), between 8:00 am and 9:00 am fasting, 16 hours after their last meal, had $15 \mathrm{~mL}$ of venous blood for biochemical markers taken.

Measurements of serum levels of glucose, total cholesterol, LDL cholesterol, HDL cholesterol and triglycerides were made by colorimetric method (COBAS e 411 Roche), while immunoenzymatic assays (ELISA) were used for determination of serum levels of DHEA-S, FSH, LH, insulin, SHGB, total testosterone, androstenedione and free testosterone.

Insulin resistance was assessed by an indirect method based on the results obtained after calculating the index value HOMA-IR = insulin concentration in the serum of fasting $(\mu \mathrm{IU} / \mathrm{mL}) \times$ fasting plasma glucose levels $(\mathrm{mmol} / \mathrm{L})$ /22.5 [18].

The free androgen index (FAl) was calculated in accordance with the standard formula (FAI = [total testosterone/SHBG] $\times 100 \%$ ).

\section{Statistical analysis}

The statistical tests were conducted using computer software Excel 2007 and STATISTICA 10. The results of the survey were considered statistically significant when $p$ values $\leq 0.05$

Data were analyzed using the Mann-Whitney U test, Fisher's exact test and chi-squared test with Yates correction.

\section{RESULTS}

\section{General characteristics of the study groups}

The group of participants with abnormal uterine bleeding (AUB) and the control group were homogeneous in terms of age, height and age at menarche. The statistical 
significance for body weight, BMI, waist circumference and hip circumference, for the mean, standard deviation, and median in both groups has been proved. ( $p$-values were respectively: $p=0.03 ; p=0.03 ; p=0.05 ; p=0.04 ; p=0.006$ ) (Tab. 1).

Analysis of the menstrual cycle and the androgens features in both bleeding and control groups

The occurrence of regular menstrual cycles $(30.23 \%$, $\mathrm{p}=0.006$ ) was significantly lower in the juvenile bleeding group. Also, secondary amenorrhea was significantly more likely to be recognized in this group of females $(p=0.03)$ (Tab. 1).

The maximum duration of menstrual bleeding in the study group averaged at $18.1 \pm 15.5$ days, and in the control group $6.3 \pm 0.6$ days $(p<0.000001)$. In contrast, the shortest menstrual bleeding in the group of females with abnormal bleeding profile averaged $8.6 \pm 5.0$ days, respectively, and $4.9 \pm 0.7$ in the control group $(p<0.000001)$ (Tab. 1).

Hirsutism has been significantly more frequently observed in the group of bleeding in comparison to the control group ( $51.16 \%$ vs. $18.92 \%, P=0.003$ ). The length of the abnormal hair growth did not differ much between the two groups ( $17.8 \pm 6.4$ months vs $20.6 \pm 9.1$ months). There were also significant differences between hair loss, acne, and sometimes from what occurred these ailments. Although in a group of juvenile bleeding acne was relatively more frequent $(86.05 \%$ vs $78.38 \%)$, but these differences were not statistically significant $(p=0.27)$. Significant differences in the severity scale of acne between the two groups of females was observed $(p=0.04)$. In the group of females with abnormal menstrual bleeding seborrhea is also much more frequent $(60.47 \%$ vs $16.22 \%, p=0.00005)$ (Tab. 2 ).

\section{Pelvic ultrasound scan examination}

Pelvic ultrasound scan in the examined females was performed between the 3rd and 5th days of the menstrual cycle. In the juvenile bleeding group, the mean volume of the right ovary was $6.5 \pm 2.8 \mathrm{~cm}^{3}$, while in the control group $5.1 \pm 2.4 \mathrm{~cm} 3(p=0.03)$. The average volume of left ovary was $6.2 \pm 2.7 \mathrm{~cm}^{3}$ of the test group and $4.7 \pm 2.8 \mathrm{~cm}^{3}$ for the control group $(p=0.01)$. (Tab. 3).

\section{Hormones and metabolic parameters in blood serum}

FSH levels in serum were significantly lower in the group of bleeding adolescents than in the control group, while the LH concentrations in blood serum showed no difference between the two groups.Theratio of LH/FSHin the group offemales with juvenile bleeding was $1.34 \pm 0.95$ and $0.92 \pm 0.39$ respectively for the control group. These differences were not statistically

Table 1. General characteristics and course of the menstrual cycles in both study and control group (mean \pm SD, median, 5 th percentile, 95th percentile)

\begin{tabular}{|c|c|c|c|}
\hline & Study group & Control group & $\mathbf{p}$ \\
\hline Age [years] & $\begin{array}{l}15.3 \pm 1.6 \\
{[16.0](13.0 ; 18.0)}\end{array}$ & $\begin{array}{l}15.6 \pm 1.6 \\
{[16.0](13.0 ; 18.0)}\end{array}$ & NS $(p=0.50)^{a}$ \\
\hline Height $[\mathrm{cm}]$ & $\begin{array}{l}163.2 \pm 6.1 \\
{[163](151 ; 172)}\end{array}$ & $\begin{array}{l}163.6 \pm 5.0 \\
{[164](155 ; 172)}\end{array}$ & NS $(p=0.84)^{a}$ \\
\hline Weight [kg] & $\begin{array}{l}56.8 \pm 10.4 \\
{[55.0](45.1 ; 75.3)}\end{array}$ & $\begin{array}{l}61.7 \pm 10.4 \\
{[57.8](50.0 ; 81.0)}\end{array}$ & $p=0.03^{a}$ \\
\hline BMI & $\begin{array}{l}21.4 \pm 3.9 \\
{[20.4](16.5 ; 28.8)}\end{array}$ & $\begin{array}{l}22.9 \pm 3.5 \\
{[22.0](19.0 ; 30.7)}\end{array}$ & $p=0.03^{a}$ \\
\hline Waist circumference $[\mathrm{cm}]$ & $\begin{array}{l}70.7 \pm 7.8 \\
{[68.5](61.1 ; 84.9)}\end{array}$ & $\begin{array}{l}74.5 \pm 8.6 \\
{[72.0](65.5 ; 93.0)}\end{array}$ & $p=0.04^{a}$ \\
\hline Hip circumference $[\mathrm{cm}]$ & $\begin{array}{l}93.3 \pm 8.1 \\
{[92.0](84.0 ; 107.7)}\end{array}$ & $\begin{array}{l}98.5 \pm 7.5 \\
{[97.5](84.5 ; 110.1)}\end{array}$ & $p=0.006^{a}$ \\
\hline Menarche [age] & $\begin{array}{l}12.6 \pm 1.2 \\
{[12](11.0 ; 15.0)}\end{array}$ & $\begin{array}{l}13.0 \pm 1.0 \\
{[13](11.8 ; 14.2)}\end{array}$ & $\mathrm{NS}(p=0.06)^{\mathrm{a}}$ \\
\hline The longest bleeding in the last 6 months [days] & $\begin{array}{l}18.1 \pm 15.5 \\
{[11](8 ; 55)}\end{array}$ & $\begin{array}{l}6.3 \pm 0.6 \\
{[6](6 ; 7)}\end{array}$ & $\mathrm{p}<0.000001^{\mathrm{a}}$ \\
\hline The shortest bleeding in the last 6 months [days] & $\begin{array}{l}8.6 \pm 5.0 \\
{[7](4 ; 15)}\end{array}$ & $\begin{array}{l}4.9 \pm 0.7 \\
{[5](4 ; 6)}\end{array}$ & $\mathrm{p}<0.000001^{\mathrm{a}}$ \\
\hline Irregular cycles occurrence \% & 69.77 & 40.54 & $p=0.006^{b}$ \\
\hline Secondary amenorrhea \% & 30.23 & 10.81 & $p=0.03^{b}$ \\
\hline
\end{tabular}

Statistical tests:

a - Mann-Whitney U test

b - Chi-squared test with Yates correction test 
Table 2. Analysis of the androgenization features occurrence and the size of the ovaries in both study and control group (mean \pm SD, median, 5th percentile, 95th percentile)

\begin{tabular}{|c|c|c|c|}
\hline & Study group & Control group & $p$ \\
\hline Hirsutism occurrence & $22(51.16 \%)$ & $7(18.92 \%)$ & $p=0.003^{a}$ \\
\hline Length of hirsutism occurrence [months] & $\begin{array}{l}17.8 \pm 6.4 \\
{[18](8.2 ; 24.0)}\end{array}$ & $\begin{array}{l}20.6 \pm 9.1 \\
{[24](12.0 ; 32.4)}\end{array}$ & NS $(p=0.53)^{b}$ \\
\hline $\begin{array}{l}\text { Ferriman-Gallwey score } \\
\text { [points] }\end{array}$ & $\begin{array}{l}10.3 \pm 2.5 \\
{[9](8 ; 15)}\end{array}$ & $\begin{array}{l}10.1 \pm 1.6 \\
{[10](8 ; 12)}\end{array}$ & NS $(p=0.75)^{b}$ \\
\hline Hair loss & $7(16.28 \%)$ & $2(5.41 \%)$ & NS $(p=0.12)^{a}$ \\
\hline Acne & 37 (86.05\%) & $29(78.38 \%)$ & NS $(p=0.27)^{a}$ \\
\hline Acne occurrence [months] & $\begin{array}{l}37.8 \pm 16.6 \\
{[36](17 ; 53]}\end{array}$ & $\begin{array}{l}32.0 \pm 12.5 \\
{[30](18 ; 49)}\end{array}$ & NS $(p=0.17)^{b}$ \\
\hline The severity scale of acne [points] & $\begin{array}{l}4.5 \pm 2.3 \\
{[4](1 ; 8)}\end{array}$ & $\begin{array}{l}3.3 \pm 1.8 \\
{[3](1 ; 7)}\end{array}$ & $p=0.04^{b}$ \\
\hline Seborrhoea & $26(60.47 \%)$ & $6(16.22 \%)$ & $p=0.00005^{a}$ \\
\hline
\end{tabular}

Statistical tests:

a - Fisher's Exact Test

b - Mann-Whitney U test

Table 3. The results of analysis of ultrasound scan in both study and the control group (mean \pm SD, median, 5 th percentile, 95th percentile)

\begin{tabular}{|c|c|c|c|}
\hline & Study group & Control group & $\mathbf{p}$ \\
\hline The size of the right ovary $\left[\mathrm{cm}^{3}\right]$ & $\begin{array}{l}6.5 \pm 2.8 \\
{[5.9](2.6 ; 11.9)}\end{array}$ & $\begin{array}{l}5.1 \pm 2.4 \\
{[4.3](2.8 ; 9.0)}\end{array}$ & $p=0.03^{a}$ \\
\hline The size of the left ovary $\left[\mathrm{cm}^{3}\right]$ & $\begin{array}{l}6.2 \pm 2.7 \\
{[6.6](2.6 ; 11.3)}\end{array}$ & $\begin{array}{l}4.7 \pm 2.8 \\
{[3.5](1.8 ; 9.1)}\end{array}$ & $p=0.01^{a}$ \\
\hline Endometrium length $[\mathrm{cm}]$ & $\begin{array}{l}0.73 \pm 0.22 \\
{[0.75](0.42 ; 1.00]}\end{array}$ & $\begin{array}{l}0.54 \pm 0.17 \\
{[0.55](0.29 ; 0.80]}\end{array}$ & $p=0.003^{a}$ \\
\hline Length of uterus $[\mathrm{cm}]$ & $\begin{array}{l}3.63 \pm 0.62 \\
{[3.60](2.72 ; 4.51)}\end{array}$ & $\begin{array}{l}3.28 \pm 0.58 \\
{[3.37](2.50 ; 4.12)}\end{array}$ & $\operatorname{NS}(p=0.06)^{\mathrm{a}}$ \\
\hline Length of cervix $[\mathrm{cm}]$ & $\begin{array}{l}2.97 \pm 0.57 \\
{[2.80](2.29 ; 3.97)}\end{array}$ & $\begin{array}{l}2.84 \pm 0.46 \\
{[2.80](2.20 ; 3.55)}\end{array}$ & NS $(p=0.44)^{a}$ \\
\hline Ratio of uterus and cervix length & $\begin{array}{l}1.24 \pm 0.21 \\
{[1.24](0.93 ; 1.65)}\end{array}$ & $\begin{array}{l}1.16 \pm 0.09 \\
{[1.12](1.06 ; 1.33)}\end{array}$ & NS $(p=0.10)^{a}$ \\
\hline
\end{tabular}

Statistical tests:

a - Mann-Whitney U test

significant $(p=0.15)$. There were no statistically significant differences in concentrations of DHEA-S, free testosterone, total testosterone, androstenedione, and SHBG. The value of the FAI also did not differ statistically significant between the two groups (Tab. 4).

The group of females with juvenile bleeding and the control group did not differ in levels of: total cholesterol, triglycerides and HDL cholesterol fractions in blood serum. Insulin concentrations in serum did not differ significantly, although in the test group showed a generally higher concentration $(10.02 \pm 5.02 \mathrm{uU} / \mathrm{mL})$ than controls $(7.62 \pm 4.11 \mathrm{uU} / \mathrm{mL})$. LDL lipoprotein cholesterol in serum was much lower in the treatment group $(78.6 \pm 19.8 \mathrm{mg} / \mathrm{dL})$ than in the control group $(86.0 \pm 22.3 \mathrm{mg} / \mathrm{dL})$. Serum glucose levels were significantly higher in the test group $(4.66 \pm 0.29 \mathrm{nmol} / \mathrm{L})$ than in the control group $(4.09 \pm 0.80 \mathrm{nmol} / \mathrm{L})$. Importantly it was found that the value of HOMA-IR was statistically higher in the group of females with juvenile bleeding $(2.10 \pm 1.04)$ than in the control group $(1.49 \pm 0.79)$ (Tab. 4).

In the group of females with abnormal uterine bleeding, insulin resistance by HOMA-IR $\geq 2.5$ was diagnosed significantly more often than in healthy females $(26.19 \%$ versus $5.26 \%$ ), (Fig. 1).

\section{PCOS occurrence in bleeding and control groups}

PCOS occurred more often when bleeding was of at least moderate intensity (33.33\% of this group). However in the group with mild bleeding, PCOS occurrence was $9.52 \%$ and in the control group, occurrence was only $5.41 \%$ (Fig. 2). 
Table 4. The concentration of hormones in the blood serum, and metabolic parameters in both test and control group (mean \pm SD, median 5th percentile, 95th percentile)

\begin{tabular}{|c|c|c|c|}
\hline & Study group & Control group & $p$ \\
\hline $\mathrm{FSH}[\mathrm{mIU} / \mathrm{mL}]$ & $\begin{array}{l}5.09 \pm 1.51 \\
{[4.89](2.14 ; 7.46)}\end{array}$ & $\begin{array}{l}7.49 \pm 3.03 \\
{[7.15](3.16 ; 11.91)}\end{array}$ & $p=0.0002^{a}$ \\
\hline $\mathrm{LH}[\mathrm{mlU} / \mathrm{mL}]$ & $\begin{array}{l}6.60 \pm 4.84 \\
{[5.10](2.46 ; 18.53)}\end{array}$ & $\begin{array}{l}6.77 \pm 3.85 \\
{[6.19](1.37 ; 11.82)}\end{array}$ & $\mathrm{NS}(p=0.59)^{\mathrm{a}}$ \\
\hline LH/FSH & $\begin{array}{l}1.34 \pm 0.95 \\
{[1.01](0.47 ; 3.21)}\end{array}$ & $\begin{array}{l}0.92 \pm 0.39 \\
{[0.95](0.34 ; 1.61)}\end{array}$ & $\operatorname{NS}(p=0.15)^{a}$ \\
\hline DHEA-S [ $\mu \mathrm{g} / \mathrm{dL}]$ & $\begin{array}{l}252.6 \pm 96.2 \\
{[244.1](107.5 ; 419.4)}\end{array}$ & $\begin{array}{l}212.6 \pm 87.7 \\
{[198.1](81.4346 .7)}\end{array}$ & $\mathrm{NS}(p=0.13)^{\mathrm{a}}$ \\
\hline Free testosterone $[\mathrm{pg} / \mathrm{mL}]$ & $\begin{array}{l}3.69 \pm 6.72 \\
{[2.02](0.64 ; 11.45)}\end{array}$ & $\begin{array}{l}2.17 \pm 1.52 \\
{[1.97](0.64 ; 3.40)}\end{array}$ & $\mathrm{NS}(p=0.53)^{\mathrm{a}}$ \\
\hline Total testosterone $[\mathrm{ng} / \mathrm{mL}]$ & $\begin{array}{l}0.33 \pm 0.17 \\
{[0.29](0.12 ; 0.62)}\end{array}$ & $\begin{array}{l}0.26 \pm 0.1 \\
{[0.28](0.09 ; 0.42)}\end{array}$ & $\mathrm{NS}(p=0.19)^{\mathrm{a}}$ \\
\hline Androstenedione $[\mathrm{ng} / \mathrm{mL}]$ & $\begin{array}{l}2.56 \pm 1.46 \\
{[2.24](1.11 ; 5.23)}\end{array}$ & $\begin{array}{l}2.23 \pm 0.77 \\
{[2.31](1.24 ; 2.86)}\end{array}$ & $N S(p=0.60)^{a}$ \\
\hline $\mathrm{SHGB}[\mathrm{nmol} / \mathrm{L}]$ & $\begin{array}{l}59.78 \pm 31.55 \\
{[55.07](23.61 ; 108.4)}\end{array}$ & $\begin{array}{l}53.03 \pm 14.69 \\
{[51.35](32.08 ; 76.82)}\end{array}$ & $\mathrm{NS}(p=0.64)^{\mathrm{a}}$ \\
\hline FAI & $\begin{array}{l}0.81 \pm 0.77 \\
{[0.59](0.14 ; 2.27)}\end{array}$ & $\begin{array}{l}0.53 \pm 0.27 \\
{[0.48](0.21 ; 0.91)}\end{array}$ & $\mathrm{NS}(p=0.44)^{\mathrm{a}}$ \\
\hline Total cholesterol [mg/dL] & $\begin{array}{l}139.4 \pm 25.1 \\
{[136](97 ; 183)}\end{array}$ & $\begin{array}{l}146.5 \pm 26.0 \\
{[146](96 ; 191)}\end{array}$ & $\mathrm{NS}(p=0.18)^{\mathrm{a}}$ \\
\hline Triglycerides [mg/dL] & $\begin{array}{l}83.2 \pm 30.3 \\
{[82](38 ; 136)}\end{array}$ & $\begin{array}{l}83.2 \pm 44.5 \\
{[67](41 ; 190)}\end{array}$ & $\mathrm{NS}(p=0.26)^{\mathrm{a}}$ \\
\hline $\mathrm{HDL}[\mathrm{mg} / \mathrm{dL}]$ & $\begin{array}{l}51.9 \pm 12.8 \\
{[51](35 ; 72)}\end{array}$ & $\begin{array}{l}51.0 \pm 14.9 \\
{[48](31 ; 86)}\end{array}$ & $\mathrm{NS}(p=0.48)^{\mathrm{a}}$ \\
\hline LDL [mg/dL] & $\begin{array}{l}78.6 \pm 19.8 \\
{[95](56 ; 126)}\end{array}$ & $\begin{array}{l}86.0 \pm 22.3 \\
{[86](55 ; 124)}\end{array}$ & $p=0.001^{a}$ \\
\hline Glucose (nmol/L) & $\begin{array}{l}4.66 \pm 0.29 \\
{[4.60](4.30 ; 5.28)}\end{array}$ & $\begin{array}{l}4.09 \pm 0.80 \\
{[4.24](3.35 ; 4.74)}\end{array}$ & $\mathrm{p}<0.000001^{\mathrm{a}}$ \\
\hline Insulin $[\mu \mathrm{U} / \mathrm{mL}]$ & $\begin{array}{l}10.02 \pm 5.02 \\
{[8.86](3.92 ; 19.46)}\end{array}$ & $\begin{array}{l}7.62 \pm 4.11 \\
{[6.76](3.49 ; 11.75)}\end{array}$ & $\mathrm{NS}(p=0.53)^{\mathrm{a}}$ \\
\hline HOMA-IR & $\begin{array}{l}2.10 \pm 1.04 \\
{[1.86](0.89 ; 4.32)}\end{array}$ & $\begin{array}{l}1.49 \pm 0.79 \\
{[1.27](0.72 ; 2.33)}\end{array}$ & $p=0.01^{\mathrm{a}}$ \\
\hline
\end{tabular}

Statistical tests: ${ }^{\mathrm{a}}$ - Mann-Whitney U test

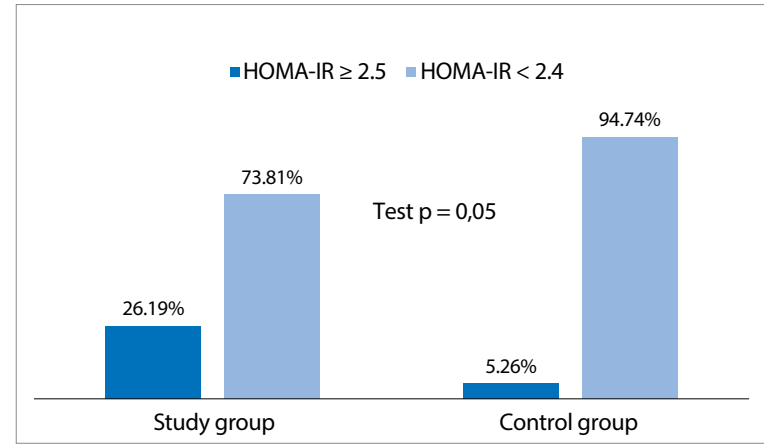

Figure 1. Insulin resistance measured by HOMA-IR in the study and control group. Statistical tests: Fisher's Exact Test

\section{DISCUSSION}

The average duration of menstrual bleeding within the group of females with heavy menstrual bleeding was

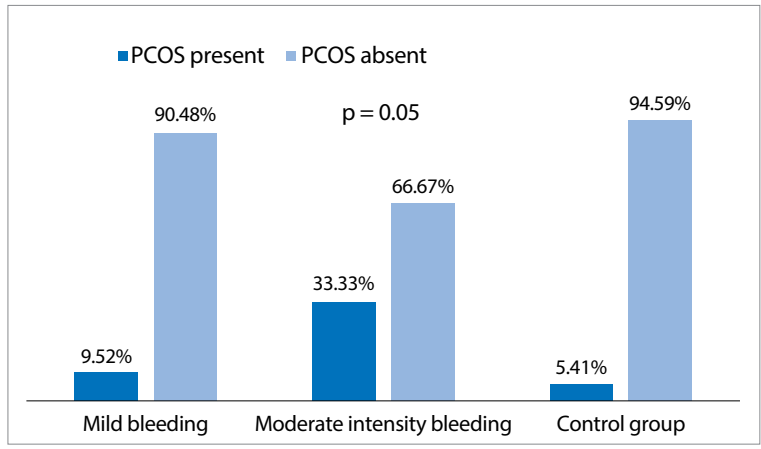

Figure 2. Frequency of PCOS in both test and control groups. Statistical tests: Mann-Whitney U test

$18.1 \pm 15.5$ days, and the range was high, ( 8 to 55 days, between the 5 th and 95 th percentiles). This demonstrated a complex clinical picture of juvenile bleeding. 
The limited existing research in young females with heavy and prolonged menstrual bleeding does not allow comparison of the results of this study with other studies accurately.

For instance, one study conducted in a group of young Turkish females with heavy menstrual bleeding also assessed the duration. This included 31 females who were diagnosed with abnormal uterine bleeding (AUB) and anemia, with an average age of 15.3 years (12-19 years). Their results were similar to those in this study; demonstrating a large discrepancy in the length of menstrual bleeding (4-90 days). The average length of menstrual bleeding was $22.6 \pm 20.0$ days. The limitation of these results is, unfortunately, a small study group [23].

Our study showed AUB was significantly more frequent in the group of females with juvenile bleeding in comparison the control group $(p=0.006)$. AUB was diagnosed in $69.77 \%$ of females with juvenile bleeding, whereas $59.46 \%$ of females in the control group had a regular menstrual period. This study also highlighted the presence of secondary amenorrhea among the surveyed females, being diagnosed more frequently in the group of females with AUB $(p=0.03)$ [24].

Similar observations were obtained by a study of Brazilian females aged between 12-19 years old. It is worth noting that only females who were at least 2 years after menarche qualified for this particular study. Out of all the participants, more than half $(61 \%)$ had irregular menstrual cycles and $69 \%$ were diagnosed with PCOS. Secondary amenorrhea was identified in $13.56 \%$ of all females who have taken part in this study [25].

A study by Shah et al. [26] also showed a high frequency of irregular menstrual cycles among young females (50.9\%), and $29.4 \%$ of teenagers had secondary amenorrhea (absence of menstrual bleeding for $>3$ months).

Our study also found that more than half of females diagnosed with juvenile bleeding (51.16\%) also had hirsutism. An increased incidence of acne was also observed $(86.05 \%)$, and the scale of severity was significantly higher compared to the control group $(p=0.04)$. Females with juvenile bleeding experienced seborrhea significantly more often compared to the control group ( $p=0.00005)$. These results indicate a higher occurrence of features of androgenization in the group experiencing juvenile bleeding. This group may be more prone to developing PCOS in adolescence or adulthood (in adolescence some females may not present the complete clinical picture of the disease).

Hyperandrogenism (or androgen excess) in young females has been the subject of several studies. The example of this is a prospective cohort study conducted in Finland with a large population of females, confirmed that hyperandrogenism in adolescence was associated with a higher incidence of PCOS in adulthood. West et al., conducted a study on a group of 2.448 females aged between 15 and 16 years old. They assessed the occurrence of PCOS, hirsutism, acne and pregnancy problems in a group of females after 10 years of follow-up. The study found that females with irregular menstrual cycles at the age of 16 also experienced significantly more skin problems, such as acne and hirsutism, at age 26, compared to females with regular menses $(p=0.049)$. The study also found that adult women with PCOS had significantly higher serum testosterone levels ( $p=0.011)$ and higher FAI $(p=0.013)$ in adolescence compared to the group with regular menses. Similarly, women with hirsutism aged 16 presented significantly lower concentrations of SHBG in the blood serum $(p=0.003)$ and higher FAI ( $p=0.001)$. Also, women with a history of acne also had significantly higher levels of testosterone $(P=0.041)$, higher FAI $(p<0.001)$ and significantly lower levels of SHBG $(p=0.003)$ compared to women without a history of acne [27].

On the other hand, a study by Pinola et al. [28] on a large group of Finnish females aged 15-16 years confirmed significantly higher levels of testosterone $(p=0.0010)$, lower levels of SHBG ( $p=0.042)$ and higher values FAI $(p=0.002)$ in the group of females with irregular menstrual cycles compared to those with regular cycles. These studies show that menstrual disorders in adolescence are a possible indicator of hyperandrogenism, and may be an early risk factor for polycystic ovarian syndrome in adulthood [23].

Analyzing the biochemical parameters between the group diagnosed with juvenile bleeding and the control groups demonstrated that the concentration of FSH was significantly lower $(p=0.0002)$ in the juvenile bleeding group compared to controls. No significant differences in concentrations of DHEA-S, free testosterone, total, androstenedione, SHBG and FAI values between the two groups of females were found. The glucose concentration $(p<0.000001)$ and the fraction of LDL cholesterol $(p=0.001)$ in blood serum differed significantly between the study group and control group. This study also found that the value of HOMA-IR was significantly higher $(p=0.01)$ in the juvenile bleeding group than in controls.

It has been hypothesized that young adolescents who experience juvenile bleeding are at risk of PCOS. This study is supported by the current research available. PCOS was more often diagnosed in the group with abnormal menstrual bleeding. There was also a correlation between the severity of bleeding and the incidence of PCOS syndrome. PCOS was more often diagnosed in the group of moderate and severe bleeding (33.3\%). In the group with mild bleeding PCOS was diagnosed in $9.24 \%$ of the females, while in the control group it was diagnosed in $5.41 \%$ of females $(p=0.05)$. These studies differ slightly from the 
results of the Basaran et al. on the Turkish population of females with heavy menstrual bleeding. This study involved 36 young females (mean age $13.7 \pm 1.4$ years) diagnosed with juvenile bleeding. Only one patient was diagnosed with PCOS (2.8\%). However, $25 \%$ of the study group of females were diagnosed with coagulation disorders [23]. It would appear that the differences between our studies and those conducted in Turkey are due to the different etiologies of heavy menstrual bleeding. Unfortunately, in the study by Basaran et al., there is no information about the duration of menstrual cycles, relation of LH/FSH and diagnostic criteria used for diagnosis of PCOS. It was therefore difficult to determine whether abnormal menstrual bleeding was connected to the lack of ovulation, and to what extent [23].

Vrbikova et al. [29], studied the prevalence of metabolic syndrome among Czech young females with PCOS and demonstrated that juvenile bleeding occurred in $6.97 \%$ of teens with PCOS. This American study also confirmed the presence of heavy menstrual bleeding in adolescent females with PCOS (3.9\%) [26].

Literature available about the presence of PCOS in groups of females with the juvenile bleeding is limited. Few studies show the existence of PCOS in this group, but do not define a direct relation between juvenile bleeding and PCOS $[23,26,29]$.

There were some limitations in this research which may affect its interpretation. The first limitation was the relatively small number of cases. This makes it more difficult to generalize findings to the entire group of females with juvenile bleeding, and the results should be treated as preliminary. Another limitation of the study was that the assessment of menstrual cycles and the duration of menstrual bleeding were retrospective in nature and therefore their assessment may have been less accurate.

Despite these limitations of the study, its novel findings should be highlighted, and the results should be considered as preliminary to extend the research on a larger population of females. To assess the long-term consequences of juvenile bleeding in adolescence, a prospective cohort study assessing the health of the same study group when they are fully mature should be also carried out.

\section{CONCLUSIONS}

Juvenile bleeding may be a risk factor of PCOS. The authors recommend performing screening studies in females with a high degree of risk for the development of polycystic ovarian syndrome, such as irregular menstrual cycles, the occurrence of excessive male type hair and acne. Such measures may reduce the risk of developing metabolic disorders and consequently improve the long-term health of young women [20, 30-32].

\section{Author's Contributions}

E.U. - concept and design, data analysis, interpretation of data collection, compilation and preparation of the manuscript. L.H. - final approval of the manuscript. M.O-G. - data analysis and interpretation, final approval of the manuscript. V.S.-P. - final approval of the manuscript.

A.S-F. - analysis and data interpretation. A.D-C. - concept and design, data analysis and interpretation, the introduction of important intellectual content of the manuscript.

\section{Conflict of interests}

The authors declare no conflict of interest. The authors report no financial, personal, political, intellectual or religious conflicts of interest. The authors alone are responsible for the content and writing of the paper.

\section{REFERENCES}

1. Deligeoroglou $E$, Tsimaris $P$. Menstrual disturbances in puberty. Best Pract Res Clin Obstet Gynaecol. 2010; 24(2): 157-171, doi: 10.1016/j. bpobgyn.2009.11.001, indexed in Pubmed: 20034856.

2. Skrzypulec-Plinta V, Drosdzol-Cop A. Krwawienia młodocianych u dziewcząt - diagnostyka, postępowanie. In:, Radowicki S. (eds.). Wybrane zagadnienia z ginekologii dziecięcej i dziewczęcej. Medical Project. ; 2011: 133-144.

3. Skrzypulec-Plinta V, Drosdzol-Cop A. Krwawienia młodocianych. Prz Menopauze. 2010; 4: 228-230.

4. Jakimiuk AJ, Grzybowski W, Beta J. [Dysfunctional uterine bleeding-diagnostics and treatment]. Ginekol Pol. 2008; 79(4): 254-258, indexed in Pubmed: 18592862.

5. Wilkson JP, Kadir RA. Management of abnormal uterine bleeding in adolescents. J Pediatr Adolesc Gynecol. 2010; 23: 22-30.

6. Holland-Hall C. Obfite krwawienia miesiączkowe nastolatek - norma czy zaburzenie? Ginek Dypl. 2013; 15: 65-72.

7. Committee on Practice Bulletins-Gynecology. Practice bulletin no. 128: diagnosis of abnormal uterine bleeding in reproductiveaged women. Obstet Gynecol. 2012; 120(1): 197-206, doi: 10.1097/AOG.0b013e318262e320, indexed in Pubmed: 22914421.

8. LaCour DE, Long DN, Perlman SE. Dysfunctional uterine bleeding in adolescent females associated with endocrine causes and medical conditions. J Pediatr Adolesc Gynecol. 2010; 23(2):62-70, doi: 10.1016/j. jpag.2009.06.003, indexed in Pubmed: 20347757.

9. Wood PL, Bauman D. Gynaecological issues affecting the obese adolescent. Best Pract Res Clin Obstet Gynaecol. 2014; 20: 1-13.

10. Szydlarska D, GrzesiukW, Bar-AndziakE. Kontrowersje wokół patogenezy zespołu policystycznych jajników. Endokr Otyłość. 2010; 6: 141-146.

11. Musmar S, Afaneh A, Mo'alla H. Epidemiology of polycystic ovary syndrome: a cross sectional study of university students at An-Najah national university-Palestine. Reprod Biol Endocrinol. 2013; 11: 47 doi: 10.1186/1477-7827-11-47, indexed in Pubmed: 23688000.

12. Radomski D, Orzechowska A, Barcz E. [Present conceptions of etiopathogenesis of polycystic ovary syndrome]. Ginekol Pol. 2007; 78(5): 393-399, indexed in Pubmed: 17867333.

13. Sokkary N, Dietrich JE. Management of heavy menstrual bleeding in adolescents. Curr Opin Obstet Gynecol. 2012; 24(5): 275-280, doi: 10.1097/GCO.0b013e3283562bcb, indexed in Pubmed: 22729091.

14. Gursel T, Biri A, Kaya Z, et al. The frequency of menorrhagia and bleeding disorders in university students. Pediatr Hematol Oncol. 2014; 31(5): 467-474, doi: 10.3109/08880018.2014.886316, indexed in Pubmed: 24684279.

15. Altintas KZ, Dilbaz B, Cirik DA, et al. The incidence of metabolic syndrome in adolescents with different phenotypes of PCOS. Ginekol Pol. 2017; 88(6): 289-295, doi: 10.5603/GP.a2017.0055, indexed in Pubmed: 28727126.

16. Ozegowska KE, Pawelczyk LA. The role of insulin and selected adipocytokines in patients with polycystic ovary syndrome (PCOS) - a literature review. Ginekol Pol. 2015; 86(4): 300-304, indexed in Pubmed: 26117990. 
17. American College of Obstetrician and Gynecologists. Committee on Adolescent Healt Care. Committee Option Number 349. Miesiączkowanie w wieku dziecięcym i w okresie dojrzewania: cykl miesiączkowy jako wyznacznik stanu organizmu. Ginek Dypl. 2009; 11: 83-87.

18. Skałba P. Diagnostyka i leczenie zaburzeń endokrynologicznych w ginekologii. Medycyna Praktyczna, Kraków 2014:31-54, 57-61, 68-85, 250-270.

19. Rotterdam ESHRE/ASRM-Sponsored PCOS Consensus Workshop Group, Rotterdam ESHRE/ASRM-Sponsored PCOS consensus workshop group. Revised 2003 consensus on diagnostic criteria and long-term health risks related to polycystic ovary syndrome (PCOS). Hum Reprod. 2004; 19(1): 41-47, indexed in Pubmed: 14688154.

20. Esmaeilzadeh S, Delavar MA, Amiri M, et al. Polycystic ovary syndrome in Iranian adolescents. Int J Adolesc Med Health. 2014; 26(4): 559-565, doi: 10.1515/ijamh-2013-0335, indexed in Pubmed: 24447981.

21. Rackow BW. Polycystic ovary syndrome in adolescents. Curr Opin Obstet Gynecol. 2012; 24(5): 281-287, doi: 10.1097/GCO.0b013e32835669ff, indexed in Pubmed: 22781076.

22. Drosdzol-Cop A, Sidło-Stawowy A, SajdakD, et al. [Diagnosing polycystic ovary syndrome in adolescent girls]. Ginekol Pol. 2014; 85(2): 145-148, indexed in Pubmed: 24745161.

23. Başaran $\mathrm{HO}$, Akgül S, Kanbur NO, et al. Dysfunctional uterine bleeding in adolescent girls and evaluation of their response to treatment. Turk J Pediatr. 2013; 55(2): 186-189, indexed in Pubmed: 24192679.

24. Altay MM, Haberal A. Abnormal uterine bleeding in adolescents: treatment with combined oral contraceptive pills is effective even in hospitalized patients with bleeding disorders. Turk J Med Sci. 2008; 38: 431-435.

25. Bouzas IC, Cader SA, Leão L, et al. Menstrual cycle alterations during adolescence: early expression of metabolic syndrome and polycystic ovary syndrome. J Pediatr Adolesc Gynecol. 2014; 27(6): 335-341, doi: 10.1016/j.jpag.2014.01.002, indexed in Pubmed: 25256874.
26. Shah B, Parnell L, Milla S, et al. Endometrial thickness, uterine, and ovarian ultrasonographic features in adolescents with polycystic ovarian syndrome. J Pediatr Adolesc Gynecol. 2010; 23(3): 146-152, doi: 10.1016/j. jpag.2009.07.002, indexed in Pubmed: 19733099.

27. West $\mathrm{S}$, Lashen $\mathrm{H}$, Bloigu A, et al. Irregular menstruation and hyperandrogenaemia in adolescence are associated with polycystic ovary syndrome and infertility in later life: Northern Finland Birth Cohort 1986 study. Hum Reprod. 2014; 29(10): 2339-2351, doi: 10.1093/humrep/deu200, indexed in Pubmed: 25085801.

28. Pinola $\mathrm{P}$, Lashen $\mathrm{H}$, Bloigu $\mathrm{A}$, et al. Menstrual disorders in adolescence: a marker for hyperandrogenaemia and increased metabolic risks in later life? Finnish general population-based birth cohort study. Hum Reprod. 2012;27(11):3279-3286, doi: 10.1093/humrep/des309, indexed in Pubmed: 22933528.

29. Vrbíková J, Zamrazilová $H$, Sedláčková $B$, et al. Metabolic syndrome in adolescents with polycystic ovary syndrome. Gynecol Endocrinol. 2011; 27(10): 820-822, doi: 10.3109/09513590.2010.508851, indexed in Pubmed: 20807165.

30. Li L, Chen X, He Z, et al. Clinical and metabolic features of polycystic ovary syndrome among Chinese adolescents. J Pediatr Adolesc Gynecol. 2012; 25(6): 390-395, doi: 10.1016/j.jpag.2012.07.006, indexed in Pubmed: 23089573.

31. Fulghesu A, Magnini R, Portoghese $E$, et al. Obesity-related lipid profile and altered insulin incretion in adolescents with polycystic ovary syndrome. J Adolesc Health. 2010; 46(5): 474-481, doi: 10.1016/j. jadohealth.2009.10.008, indexed in Pubmed: 20413084.

32. Nidhi R, Padmalatha V, Nagarathna R, et al. Prevalence of polycystic ovarian syndrome in Indian adolescents. J Pediatr Adolesc Gynecol. 2011; 24(4): 223-227, doi: 10.1016/j.jpag.2011.03.002, indexed in Pubmed: 21600812 